\title{
National Music Promotion and Inheritance Strategies Based on the Perspective of Intangible Cultural Heritage
}

\author{
Lu Kang \\ Beijing Song and Dance Theater Co., Ltd., Beijing 100021, China \\ DOI: $10.32629 /$ asc.v2i4.587
}

\begin{abstract}
Folk music is a heavy cultural carrier. Today, when culture is flourishing, it still has a unique charm and appeal. The intangible heritage of national music requires modern Chinese to continue to carry forward and inherit it, so that the spirit and characteristic culture contained in it can be smoothly transformed into the fruits of education. For this reason, it will be a feasible idea to promote and inherit national music from the perspective of intangible cultural heritage with academies education as the central medium. The article combines the understanding of intangible cultural heritage and the thinking on the promotion and inheritance of ethnic music from the perspective of intangible heritage, and further explores the significance and strategy of the promotion and inheritance of ethnic music centered on vocal music teaching in colleges and universities, hoping to provide valuable reference for relevant research.
\end{abstract}

Keywords: intangible cultural heritage, folk music, promotion, inheritance

National music is an art born out of the lives of the people of various nationalities, and it is also the crystallization of a culture that is close to the hearts of the people of various nationalities. Therefore, ethnic music seems simple, but in fact it is rich in content and large in volume. It can be used as a window of cultural exploration, and the far-reaching significance of promotion and inheritance is self-evident. Obviously, the attribute limitation of "intangible cultural heritage" is the best tribute to national music and can also promote its innovative development. Among all the methods of cultural promotion and inheritance, education is the core and the most effective. Therefore, major colleges and universities will become the best nodes for the promotion and inheritance of folk music.

\section{About the understanding of intangible cultural heritage}

Intangible cultural heritage can be tangible or intangible; it can be a specific artifact or a certain cultural activity. It is closely related to the life of the masses, arises in life, and is passed on from generation to generation by the masses. It can be expressed as a form of traditional culture, such as traditional skills and knowledge, folk activities, performing arts, etc. (intangible), or living utensils, handmade products, etc. (tangible), and can also be expressed as a relative cultural space, such as A venue for special festivals or celebrations. All things used to carry and express intangible cultural heritage can be regarded as its cultural elements. These elements complement each other, connect with each other, and are preserved and spread by mankind together.

\section{Ideas for the promotion and inheritance of national music from the perspective of intangible cultural heritage}

Currently, a government-led "protection" campaign for intangible cultural heritage is being launched on a large scale across the country ${ }^{[1]}$. From the perspective of intangible cultural heritage, the development of national music should be promoted in a large scale and effective in inheritance. The effective achievement of this goal requires education. Therefore, the idea of the article is that in the development of national music, it should be based on its "cultural standard" attributes, incarnate into effective educational materials, penetrate into the talent training practice of colleges, and finally form a college education as the center. The promotion and inheritance of traditional culture radiated by national music culture is gradually carried out to the society.

In the relevant education of colleges and universities, the idea of how to embody the intangible cultural heritage of ethnic music is to effectively sort out the internal semantic relations between the inheritance, protection and development of ethnic music culture in teaching, so that students can stand in a correct understanding Learn it, master it, and even carry it forward on a level. Among them, inheritance refers to a process of natural dissemination and inheritance based on longing for culture. Protection refers to the awareness and recognition of culture so that it can be effectively developed and spread without being 
damaged. Development refers to the transfer and inheritance of culture, to re-understand it, and then to innovate and create. At the same time, in view of the special background of ethnic music, the original development space is relatively closed. It can be said that it has a relatively independent "cultural ecosystem". Therefore, the education and teaching of colleges and universities should be able to make students realize that they are I'm learning "Whose Music", "Whose Culture", and "Who is Singing". In this way, they can well distinguish the subject and object in the study and inheritance of ethnic music culture, and then form a correct cultural concept.

\section{The significance of promoting and inheriting national music centered on vocal music teaching in colleges and universities}

As a special symbol of culture, ethnic music contains rich educational resources ${ }^{[2]}$. Our national music has strong Chinese national characteristics ${ }^{[3]}$. As an important output position of social music talents and an important promoter of social, economic and cultural development, colleges and universities must actively play their own functions, and effectively carry out the innovative practice of integrating national music culture into music-related professional teaching, so as to develop and open up more for the inheritance, development, and innovation of national music culture. Multiple roads create a new splendor of national culture ${ }^{[4]}$. First, based on the perspective of vocal music teaching in colleges and universities, conducting curriculum-centered promotion and inheritance of folk music can enrich the content and links of vocal music teaching in colleges and universities, and make the ideological conception of teaching deeper and more educational and guiding. . my country has many ethnic groups and a long history, so the process of formation and precipitation of national music is very worthy of study, and the content worthy of excavation is particularly rich. They can become a rich material for college vocal music teaching; and as an art form with inherent spiritual civilization, Through the integration of national music elements in vocal music teaching, the national spirit can also be incorporated, so that young students can get ideological influence.

Second, based on the perspective of the development of intangible cultural heritage, the integration of vocal music teaching in colleges and universities into national music can improve the quality and efficiency of the promotion and inheritance of national music culture, and effectively form a cultural radiation point centered on young students to expand national music. The influence of culture. In recent years, my country has continuously increased its attention to intangible cultural heritage, and has also consciously selected excellent traditional cultures and turned them into the classroom as educational materials. This is not only because we have recognized the key significance of traditional culture, but also because we have seen the speed of development of modern society, hoping to use the weight of traditional culture to empower development and make it a balance between speed and quality. Undoubtedly, educating and guiding young students who are about to enter the practice of social construction is the most convenient and efficient way, and it can also make them a carrier of cultural radiation and dissemination. And this process will also be a process in which traditional culture can be inherited and innovated, achieving a win-win situation.

\section{Strategies for the promotion and inheritance of ethnic music centered on vocal music teaching in colleges and universities}

\subsection{Continue to enrich teaching content and enrich teaching methods}

(1) Enrichment of teaching content. Vocal music classes in colleges and universities should rely on the content of teaching materials as the most basic support, so the steps to enrich the teaching content are indispensable. The relevant teaching content of colleges and universities is sufficient, and attention should be paid to reflect the appropriate integration of national music, and to make the selected national music content compatible with the teaching theme. Among them, in the vocal music teaching materials of colleges and universities, many ethnic music contents have been integrated, but they are lacking in systemicity and content richness. Therefore, college vocal music teachers can use the textbook content as a radiant point to expand on ethnic music, so that the teaching content can be enriched; colleges and universities can also organize vocal music teachers to compile ethnic music school-based textbooks as a characteristic auxiliary teaching tool. In order to expand students' musical horizons. In the compilation of school-based teaching materials, teachers with a profound ethnic cultural background can be used as leaders to improve the consciousness of ethnic music integration in the compilation of teaching materials.

(2) Abundant teaching methods. In the practice of vocal music teaching in colleges and universities, teachers are able to recognize the direct impact of the use of teaching methods on the teaching effect, so they can actively explore more diversified teaching methods. For example, they continue to use the ideas of "breaking" and "standing" to innovate in the singing of musical works, and to study the integration of popular singing, bel canto singing, and national singing. This is 
indeed an innovation, and it can also bring students a novel learning experience and inspire new inspiration. However, the personal abilities of some vocal music teachers are limited. Because of their accumulated teaching experience, they are better at vocal singing skills and can guide students to carry out relatively effective exercises. However, some vocal music teachers have a poor cultural background of national music, so when integrating national music into teaching, there will be a phenomenon of focusing on skills and weak national characteristics, because the teachers themselves grasp the background, charm, and national characteristics of music. Don't get deep, don't see through. As a result, the "original" nature of folk music teaching in college vocal music classes is insufficient. This is not conducive to the high-quality promotion and inheritance of folk music. Therefore, based on the richness of teaching methods, vocal music teachers should strengthen the expression of the characteristic charm of national music based on the teaching of vocal skills. Teachers can comprehensively use flipped classrooms, situational teaching methods, mixed teaching methods, etc., and incorporate micro-class production, MOOC resource application, etc., so that vocal music teaching is not limited to a fixed form, so that students can be autonomous In the process of emphasizing, become an explorer and excavator of the elements and charm of national music in order to increase the connotation of national culture. In addition, in order to increase students' emphasis on national music and urge them to practice national music singing in and out of class, teachers can highlight the connection between national music and different singing methods such as bel canto and folk singing, so that they can naturally In daily practice, he draws inferences about national music knowledge. For example, teachers can instruct students to learn the reference part of folk singing to Bel Canto so that they understand that after the two are merged, the state of ethnic voices will become more high-pitched, high-positioned, wide-ranging, and mainly mixed. This broadens the students' cognition of national music and enables them to look at different music forms with a more dialectical perspective.

\subsection{Pay attention to the integration of ideological and political elements in vocal music teaching}

The inheritance of intangible cultural heritage is of great significance to individuals, but it lacks relatively specific performance in the cognition of young students. Therefore, the young students will be in a daily unconscious state in the inheritance of intangible cultural heritage, and their initiative is naturally weak. With the changes of social culture, the current college students' enthusiasm for learning ethnic music has declined ${ }^{[5]}$. In order to promote and inherit national music with the help of college vocal music teaching, vocal teachers should pay attention to the integration of ideological and political elements in the teaching process, so that young students can discover the value of national music inheritance and adopt a correct attitude, Prerequisite for advanced concepts and awareness, to promote and pass on national music. In the integration of ideological and political elements, vocal music teachers should pay attention to leading students to explore the ideological and political points in specific national music works, including cultural, national, and spiritual aspects. For example, in the song "Qinghai-Tibet Plateau", the excavation of cultural ideological and political elements can mainly focus on the lyrics. "Song without words" "I see mountains and rivers, and mountains and rivers connected", expresses the deep affection and infinite hope for the magnificent rivers and mountains of the motherland-patriotism. The mining of ideological and political elements at the national level can be started from the tune and singing of the song. It is also the phrase "Song without Words", using a long tone, which brings people to the infinite nostalgia for the great rivers and mountains of the motherland through the auditory experience. As for the ideological and political elements on the spiritual level, vocal music teachers can pay attention to the background of songs and the historical background of Tibetan development. The addition of ideological and political elements can enrich the learning process of national music for students, and the learning results they obtain will be equally rich, which will help them become qualified promoters and inheritors of national music culture.

\section{Conclusion}

In summary, the preciousness of intangible cultural heritage requires modern people to continuously improve their understanding of its inheritance and take effective actions to promote its innovation and development. As the main responsibility unit of education, colleges and universities have abundant educational resources, strong teaching staff, and strong appeal and guidance to young students, and they should assume the historical and social responsibilities for the promotion of intangible cultural heritage. Colleges and universities should achieve the goal of education and guidance through the rational integration of national music and vocal music education, and continue to cultivate inheritors of intangible cultural heritage for the society. The strategies listed in the article still have deficiencies and limitations, which require teachers to constantly supplement and adjust them in the practice of vocal music teaching. 


\section{References}

[1] Lan Xuefei. On the mutual call between the intangible music cultural heritage movement and the academic research of ethnic music - Also on the good opportunities for the practice of ethnic music education[J]. People's Music, 2021(4):48-51.

[2] Chen Chen, Wang Zhijun. Some Thoughts on National Music Education in Chinese Colleges and Universities from the Perspective of Cultural Confidence[J]. The Voice of Yellow River, 2020(8): 2.

[3] Zhang Lihong, Yin Aiqing. On the construction and perfection of our national music teaching system [J]. Journal of Northeast Normal University (Philosophy and Social Sciences), 2021(2):198-201.

[4] Hu Xiaojie. Music Teaching in Colleges and the Inheritance of National Music Culture - A Review of "Research on Teaching Strategies of Music Culture in Colleges and Universities"[J]. Chinese Journal of Education, 2021(3):1.

[5] Zhou Hui. The construction of the national music teaching system in colleges and universities - Comment on "Introduction to Ethnomusicology"[J]. Higher Education Exploration, 2020(3):1. 